\title{
Józef Półturzycki, Spór o kształcenie ustawiczne. Polemiki i analizy, Wydawnictwo ITEE, Warszawa-Radom 2016, ss. 428
}

Idei kształcenia ustawicznego poświęcono wiele publikacji, jej początki odnajdujemy już w dziełach starożytnych autorów, w ich postawie i potrzebie uczenia się przez całe życie. Kolejne epoki to również popularyzowanie idei ustawiczności kształcenia. Jan Amos Komeński w Pampedii wskazał, że dla ludzi całe życie jest szkołą, „każdy wiek jest odpowiedni do uczenia się, a życie ludzkie nie ma innego celu jak nauka" (s. 9, 70).

Monografia profesora Józefa Półturzyckiego Spór o kształcenie ustawiczne. Polemiki i analizy stanowi dogłębną interpretację dotychczasowych publikacji autorskich i zbiorowych, raportów, badań i analiz w ośrodkach uniwersyteckich i szkołach wyższych w kraju i za granicą, a także stanowisk w podejściu do problematyki ustawiczności kształcenia. Półturzycki to ceniony pedagog, dydaktyk, andragog, współpracujący ze specjalistami wielu naukowych ośrodków międzynarodowych, m.in. w zakresie kształcenia ustawicznego. Interdyscyplinarne kompetencje i wiedza profesora w obszarze andragogiki, teorii kształcenia, metodyki nauczania języka i literatury polskiej poszerzają i ugruntowują pole analiz teorii i praktyki edukacji całożyciowej.

Polskie uniwersytety i szkoły wyższe realizują ideę edukacji całożyciowej poprzez publikacje, badania, raporty, organizację konferencji, działający Zespół Pedagogiki Dorosłych przy Komitecie Nauk Pedagogicznych PAN, wybrzmiewa ona także w profilach i programach kształcenia uniwersyteckiego na kierunkach pedagogicznych. Przykładem jest Uniwersytet Warszawski, w którego dwusetną działalność wpisuje się Wydział Pedagogiczny z czołowymi przedstawicielami - profesorami pedagogami: Bogdanem $\mathrm{Na}$ wroczyńskim, Bogdanem Suchodolskim, Ryszardem Wroczyńskim, Łukaszem Kurdybachą, Ireną Wojnar, Eugenią Anną Wesołowską, Wincentym Okoniem, którego profesor Józef Pólturzycki jest uczniem. Tradycje idei 
edukacji ustawicznej na Uniwersytecie Warszawskim uświetniają tym samym jego dwusetną rocznicę powstania.

Prezentowana monografia została opracowana w postaci 10 rozdziałów, które odnoszą się do: genezy sporu o kształcenie ustawiczne, podstaw i tendencji rozwojowych edukacji ustawicznej, polskich prób ujęcia edukacji ustawicznej, jednostronnego i niepełnego ujęcia edukacji ustawicznej, konsekwencji kształcenia ustawicznego dla procesu nauczania, szkolnictwa wyższego a idei edukacji ustawicznej, samokształcenia jako podstawowego procesu edukacji ustawicznej, edukacji dorosłych a kształcenia ustawicznego, technologii i kultury w kształceniu ustawicznym, wartości i rozdroży edukacji ustawicznej.

Półturzycki odwołuje się także do swoich autorskich publikacji (Tendencje rozwojowe kształcenia ustawicznego, Wdrażanie do samokształcenia, Dydaktyka dorostych, Dydaktyka dla nauczycieli, Akademicka edukacja dorosłych) i współautorskich wcześniejszych opracowań, m.in. Kształcenie ustawiczne podstawa nowoczesnej edukacji (Frąckowiak, Półturzycki 2011). Zwracano w niej uwagę obok wartości idei ustawiczności kształcenia na różnorodność, często niespójność, powierzchowność, swobodę, nierzetelność naukową, a nawet niechęć wielu współczesnych autorów w przedstawianiu istoty procesu kształcenia ustawicznego oraz chęć podważania i zwalczania idei edukacji ustawicznej. Wywołuje to oczywisty niepokój o stan, dorobek i przyszłość kształcenia ustawicznego wśród jego popularyzatorów (s. 10).

W świetle dwusetnej rocznicy powstania Uniwersytetu Warszawskiego i jego tradycji pedagogicznych, w tym - co istotne - andragogicznych, Półturzycki przywołuje ważną dla dorobku polskiej edukacji ustawicznej, habilitacyjną rozprawę A. Frąckowiak Kształcenie ustawiczne i szkoły wyższe - niedostrzegany potencjat, opublikowaną w 2012 roku. Wśród współpracowników i uczniów profesora Półturzyckiego ze zróżnicowanym stażem, doświadczeniem naukowym i zawodowym, są profesorowie, doktorzy, absolwenci uniwersytetów i szkół wyższych, autorzy opracowań traktujących szeroko o praktyce i teorii kształcenia ustawicznego, do których Półturzycki często nawiązuje.

Rozdział I monografii dotyczy genezy sporu o kształcenie ustawiczne jako idei wyznaczającej także nurt współczesnej edukacji w kraju i na świecie. Półturzycki przywołuje zróżnicowane koncepcje ustawiczności kształcenia Francji, Stanów Zjednoczonych, Kanady, Norwegii, Wielkiej Brytanii, Niemiec. W wielu krajach popularyzowano ideę ustawiczności jako edukację dorosłych poprzez różne formy kształcenia i doskonalenia zawodowego. Założeniem edukacji ustawicznej stała się potrzeba całożyciowego, perma- 
nentnego rozwoju człowieka, w tym potrzeba ustawicznego kształcenia, wychowania i co bardzo ważne - samokształcenia. Stanowi to podstawę samodzielności, dojrzałości, dorosłości, autonomii jednostki w podejmowaniu ról życiowych, społecznych, zawodowych. Problematyka rozwoju człowieka i zmian w cyklu życia mieści się w obszarze wielu interdyscyplinarnych nauk, odnosi się także do filozofii, aksjologii, psychologii, antropologii, medycyny, poszukujących odpowiedzi na pytania o cel życia, jego jakość i wartości.

Półturzycki przywołuje wielość publikacji, opracowań, badań, raportów, analiz, sympozjów, konferencji, towarzystw i komitetów, które nadały kształt współczesnej edukacji ustawicznej. Powołuje się także na znane raporty Edgara Faure’a Uczyć się, aby być oraz J. Delorsa, ważnych w rozwoju kształcenia permanentnego. Niestety, jak wskazuje Półturzycki, reformy edukacyjne i kolejne lata modernizacji kształcenia ustawicznego, będące konsekwencją m.in. Strategii rozwoju kształcenia ustawicznego w Polsce do 2010 roku, spowodowały chaos pojęciowy i niejednoznaczność - edukację ustawiczną utożsamiano tylko $z$ edukacją dorosłych, a nie całokształtem edukacji powszechnej, z kształceniem w placówkach różnych profili i etapów i samokształceniem. Kształcenie ustawiczne traktowano także jako doskonalenie zawodowe pracujących. Idea kształcenia ustawicznego łączy się z edukacją dorosłych poprzez różne formy kształcenia instytucjonalnego i samokształcenia. Edukacja dorosłych zawiera się w kształceniu ustawicznym jako jego wczesna postać. Kształcenie ustawiczne to proces całożyciowego, permanentnego rozwoju i edukacji, to kształcenie instytucjonalne i pozaszkolne formy oraz samokształcenie.

Jak wskazuje Półturzycki, „podstawowym procesem w systemie edukacji ustawicznej jest samokształcenie, własna aktywność edukacyjna i kulturalna. Samokształcenie znajduje nowe możliwości w systemie edukacji ustawicznej i zapewnia warunki pełnej realizacji uczenia się przez całe życie" (s. 24).

Kształcenie ustawiczne powinno stanowić podstawę współczesnej dydaktyki, z wytyczeniem nowych, ważnych celów i wartości, zasad kształcenia, a także elementów procesu kształcenia: treści, programów, modeli, strategii, metod, technik uczenia się i nauczania. O potrzebie wzbogacenia tych składowych o ideę permanencji w edukacji pisał m.in. Półturzycki w pracy Niepokój o dydaktykę z 2014 roku (s. 26).

Rozdział II ukazuje ideę ustawiczności kształcenia w świetle raportów o stanie i potrzebach rozwoju edukacji. Pierwszym z nich jest ogłoszony w 1972 roku raport Edgara Faure’a Uczyć się, aby być, w którym przestawiono 21 zasad traktujących ideę edukacji permanentnej jako innowacyjną. Wynika z nich, że „edukacja permanentna nie stanowi ani systemu, ani 
dziedziny czy szczebla kształcenia, lecz jest zasadą, na której oparta powinna być oświata i życie oświatowe społeczeństwa [...]" (s. 35), natomiast "oświata dorosłych i szkolnictwo tworzą całość systemu oświatowego" (s. 37). W 1996 roku opublikowano międzynarodowy raport Delorsa Edukacja - jest w niej ukryty skarb, z którego wyłania się zasada uczenia się przez całe życie i uczenia się z życia. Podstawą permanentnej, całożyciowej edukacji powinny być cztery filary: uczenie zdobywania wiedzy, uczenie do działania, harmonijnego współżycia i uczenie do życia (s. 44). Półturzycki przywołuje także inne raporty niemieckich specjalistów w zakresie ustawiczności kształcenia oraz raport Lifelong Learning for All.

Kolejny, trzeci rozdział traktuje m.in. o marginalizacji kształcenia ustawicznego w raportach o stanie oświaty w Polsce. Półturzycki odwołuje się do ważnej strategii kształcenia ustawicznego do 2010 roku, przyjętej w 2003 roku, uznając tan dokument za trafny, choć niedopracowany, zawierający błędy definicyjne, m.in. w pojmowaniu edukacji dorosłych jako kształcenia ustawicznego (s. 105). Dominuje w nim m.in. pogląd, że „dziedziny oświaty dorosłych tworzą system kształcenia ustawicznego" (s. 106). W toku dyskusji pojawiały się różne propozycje, uznające drożność systemu szkolnego, w tym również zawodowego, z kształceniem wyższym, podyplomowym, kursowym jako składowych systemu kształcenia ustawicznego lub jak w Wielkiej Brytanii - kształceniem dalszym. Oświata dorosłych zatem, jako pojęcie węższe, jest podporządkowana edukacji ustawicznej. Raport o stanie edukacji ustawicznej z 2005 roku rekomenduje wprawdzie potrzebę zmian w zakresie kształcenia ustawicznego, jednakże nie stał się przedmiotem szerszej dyskusji. Jego wadą w ocenie Półturzyckiego jest „sprowadzenie kształcenia ustawicznego do nauki w szkołach i na kursach zawodowych oraz doskonalących" (s. 137).

W kolejnym, czwartym rozdziale pracy Półturzycki nawiązuje m.in. do konferencji z 2013 roku Całożyciowe uczenie się jako wyzwanie dla teorii i praktyki edukacyjnej, zorganizowanej przez UAM w Poznaniu i publikacji pokonferencyjnej poświęconej podejmowanej problematyce. Z niepokojem zauważa niejasność, jednostronność ujęcia ustawiczności i całożyciowego uczenia się głównie jako doskonalenia zawodowego. Ilustruje także trajektorie kształcenia ustawicznego i niespójności w innych opracowaniach.

Rozdział V poświęcony jest konsekwencjom kształcenia ustawicznego dla procesu nauczania. Czytamy w nim o propozycjach Instytutu Pedagogicznego UNESCO w Hamburgu. Opracowany w 1974 roku raport wyznacza wartości rozwoju edukacji permanentnej, właściwych dla państw rozwijających się. Zapisano w nim m.in., iż „istotną podstawę kształcenia stanowią 
trzy terminy: życie, kształcenie i permanencja [...] kształcenie nie może być zamknięte w szkole, lecz ma obejmować całe życie człowieka [...] kształcenie ustawiczne nie oznacza tylko kształcenia dorosłych, lecz obejmuje wszystkie etapy i okresy życia człowieka [...] składa się z formalnych i nieformalnych działań [...]" (s. 178-179).

Półturzycki zauważa, że kształcenie ustawiczne i całożyciowe uczenie się to wyzwania nie tylko andragogiki, ale także współczesnej dydaktyki jako teorii kształcenia i samokształcenia, odnoszącej się do kształcenia dzieci, młodzieży i dorosłych w systemie edukacji instytucjonalnej i pozaszkolnej, równoległej, połączonych z samokształceniem. Niepokój autora wzbudza brak w opracowaniach z zakresu dydaktyki ujęcia kształcenia ustawicznego i edukacji całożyciowej.

W rozdziale VI - Szkolnictwo wyższe a idea edukacji ustawicznej, autor omawia dokumenty - wytyczne dla Europejskiego Obszaru Szkolnictwa Wyższego. W rozdziale tym znajdujemy wyjaśnienia w różnym pojmowaniu idei kształcenia ustawicznego dla przemian oświatowych. Kształcenie ustawiczne nadal pojmowane jest jako edukacja dorosłych z dominującą rolą nauczycieli - grupy zawodowej permanentnie doskonalącej się. Dla rozwoju kształcenia ustawicznego istotna stała się idea otwartości kształcenia (otwartość na potrzeby kształcenia różnych środowisk, otwartość na nowe treści, formy, metody, na nowy typ relacji wykładowca-student) wraz z rozwojem uczelni otwartych. Półturzycki ilustruje przykłady uniwersytetów otwartych w różnych krajach oraz ich osiągnięcia w praktyce oświatowej i teorii pedagogicznej (s. 228-238).

Rozdział VII poświęcono samokształceniu jako podstawowemu procesowi edukacji ustawicznej. Pojęcie samokształcenia, jak wskazuje autor, jest różnie definiowane i interpretowane, jest głównie procesem samodzielnym, indywidualnie i świadomie podejmowanym działaniem, ale może także być wspierane pomocą innych w celu rozbudzenia motywacji i aktywności poznawczej. Samokształcenie zdaniem Półturzyckiego ma także być procesem ustawicznym, nazywanym ustawicznym samokształceniem.

W rozdziale VIII znajdujemy interpretacje edukacji dorosłych w kontekście kształcenia ustawicznego. Autor odwołuje się do Raportu UNESCO w sprawie rozwoju i upowszechnienia edukacji dorosłych z 1976 roku. Istotna dla zmian była także ogłoszona 1996 roku hamburska deklaracja edukacji dorosłych, w której edukacja dorosłych traktowana była jako wyzwanie XXI wieku. Określono w niej m.in. cele edukacji dorosłych i kształcenia dalszego. Nowa koncepcja edukacji dorosłych ma się opierać na sieci formalnych i nieformalnych, twórczych i elastycznych systemów. Jedną z form kształce- 
nia dorosłych jest kształcenie na odległość, kształcenie korespondencyjne, kształcenie zdalne, które może występować w relacji z nauczaniem bezpośrednim, indywidualnym i zbiorowym. Ważnym miejscem dla edukacji dorosłych są Uniwersytety Trzeciego Wieku z bogatą tradycją i ofertą nie tylko kształcenia. Rok 2012 ogłoszono jako Rok Uniwersytetu Trzeciego Wieku w Polsce.

W rozdziale IX autor wskazuje na zastosowanie komputera, Internetu, nowych technologii informatycznych jako wartości w uczeniu się, nauczaniu i samokształceniu, np. komputer jako nauczyciel - korepetytor, dostępność i korzystanie z zasobów bibliotecznych, dóbr kultury i sztuki. E-learning wyznacza kierunek zmian w zakresie modernizacji edukacji, dając możliwość wideokonferencji, szkoleń on-line, kursów e-learningowych. Zmienia się zatem postać i charakter materiałów dydaktycznych, ich przekaz i odbiór. W rozdziale tym Półturzycki nawiązuje także do kultury i edukacji ustawicznej, wskazując, że „pedagogika kultury przeżywa swój renesans i staje się na przełomie wieków wiodącym nurtem wychowania" (s. 378).

Rozdział ostatni, Wartości i rozdroża edukacji ustawicznej, stanowi wynik końcowych analiz i interpretacji, a także refleksji autora wokół edukacji ustawicznej, jej miejsca i kierunków zmian. Najbardziej rozwiniętą definicją edukacji ustawicznej jest w ujęciu Tadeusza Nowackiego określenie jej jako idei kształcenia i wychowania całożyciowego jako zasady dla całego sytemu oświatowo-wychowawczego, jako potrzeby współczesnego, dorosłego człowieka, jako systemu dokształcania i doskonalenia.

Półturzycki wskazuje na potrzebę zmian i uporządkowania terminologicznego w zakresie kształcenia ustawicznego. Prezentowana monografia jest zdaniem autora podsumowaniem zainteresowań badawczych i rezultatem wielu wnikliwych, rzetelnych analiz w tym zakresie. Praca powstawała przez wiele lat. Jest formą przemyśleń, dyskusji, polemik i wniosków „W postaci sporu o istotę, jakość i tendencje rozwojowe edukacji ustawicznej jako procesu opartego na samodzielnym doskonaleniu i samokształceniu" (s. 403). Jest to bardzo ważna praca, ukazująca naukowe tradycje, przeobrażenia i wartości kształcenia ustawicznego dla współczesnej dydaktyki, andragogiki, pedagogiki.

Elżbieta Wieczór 